\title{
Introduction: Towards a Sustainable Welfare State
}

\author{
Mary P. Murphy* and Michael McGann** (1) \\ *Maynooth University, Maynooth, Ireland \\ E-mail: mary.p.murphy@mu.ie \\ **Maynooth University, Maynooth, Ireland \\ E-mail: michael.mcgann@mu.ie
}

This themed section comes at a timely moment in social policy debate, with 2022 marking the eightieth anniversary of the publication of the Beveridge Report. Although the origins of modern welfare states can be traced to the late nineteenth and early twentieth century, Beveridge's report on Social Insurance and Allied Services foregrounded what has been described as a period of 'unprecedented and, at least to some extent, consensual growth in welfare states' (Pierson et al., 2014: 3). Setting out to address the five evils of want, disease, squalor, ignorance, and idleness - and prioritising equality, full employment and state intervention to promote welfare for individuals and society - it catalysed 'a new agenda' (Béland et al., 2021) for social policy in Britain that also shaped welfare state development in many other countries. Post the ravages of WW2, the Beveridge report mapped a blueprint to build back a more inclusive and democratic state based on contributory social insurance systems, enhanced age pensions, and universal public services in health and education where citizens would be free from deprivation and need. Eighty years later, the parallel is obvious: we are now faced with building back after the pandemic and reconstructing welfare institutions in the context of even greater near immediate challenges of climate change, loss of biodiversity, automation, and digitalisation.

This thematic section was conceived before the pandemic struck, although the Covid crisis has certainly shaped the contributions. Each contributor shares a disaffection with the productivist footing of contemporary welfare states and the underlying agenda of economic development animating much of contemporary social policy debate, where social policies are advanced as complimentary, if not means, to promoting growth and are evaluated primarily in terms of their economic impacts and employment effects (Hirvilammi, 2020). Each contribution begins from the perspective that social policies should be evaluated from the perspective of their contribution to sustainable wellbeing and human flourishing. This is both an ecological necessity, given the near impossibility of decoupling economic growth from greenhouse gas emissions (GHGs) in what little time remains to avert catastrophic climate change, and a humanist proposal, given what the contributors diagnose as an inability of contemporary welfare models to value essential reproductive activity or meet human needs. This then leads into a consideration of the kinds of reforms to income supports and public services needed to reconcile welfare states with an 'eco-social' policy orientation to enable more sustainable patterns of wellbeing and flourishing. 
These were already lively debates pre-Covid, although they were often carried out at the periphery and in specialist journals dedicated to environmental concerns (cf. Gough, 2015; Hirvilammi and Koch, 2020). Our original motivation for this thematic section was partly to 'mainstream' these debates to a broader social policy community. This need has intensified in the context of critical commentary inspired by the pandemic: regarding the kind of world we want to re-emerge into, and where to redraw the boundaries between the market and the state. The pandemic has led to increasing scrutiny as to whether welfare states are fit-for-purpose in provisioning for people's needs and in promoting longer-term sustainability from an ecological and climate perspective. Public attention on 'essential workers' has stirred critical reflexivity about the capacity of markets to provide key services and to value essential work, promoting renewed appreciation of the importance of robust public services and our mutual interdependence on often precariously employed and low-paid frontline service workers. The critical importance of social security, and the adequacy of existing income supports, has been highlighted by the shuttering of economies, the introduction and expansion of furlough schemes, temporary benefit increases, and a range of other emergency welfare measures that have seen a renewal of arguments for a universal basic income (Wignaraja and Horvath, 2020), or for permanent increases in headline social security payments by way of a minimum income guarantee (Arnold, 2020), that when combined with universal basic services becomes a social guarantee ${ }^{1}$. In parallel, issues of the environment and the relational and ecological costs of our patterns of market participation have also been brought into renewed focus (Laurent, 2020), with the Intergovernmental Panel on Climate Change warning in its sixth assessment report that we are at the tipping point of catastrophic climate change unless action is urgently taken to reduce GHGs (Thorne, 2021). The key question, addressed in various ways by the contributions to this thematic section, is how to realign social security with patterns of participation that value essential work and sustain rather than marginalise activities of reproductive value.

\section{Decoupling welfare from productivism and growth}

Since the Beveridge report was first published, welfare states have undergone enormous transformation. This reflects shifting dynamics between social and economic policy, reconfigurations of family and gender relations; and between social security and labour market participation. The welfare state has been progressively reinterpreted from an institutional means to achieve economic stabilisation and social protection from market failure, to a fiscal burden, to a means of advancing economic development through forms of 'productive social policy' (Morel et al., 2012: 11). A brief, if cursory, survey helps to contextualise the extent to which an eco-social or sustainable welfare model marks a new trajectory.

The thirty-year period following the Beveridge Report is often considered the heyday of social democracy (in Britain at least), although this characterisation is far from unproblematic (Jackson, 2013). Against the background of industrial capitalism and the imperative to mitigate the social costs of the market economy, it was a period when relatively generous social security regimes and an expansion of public services afforded a degree of decommodification. Income supports were broadly 'passive' in form, strengthening the bargaining power of workers at the peripheries of the labour market as political 
economies coalesced around a seeming settlement between the 'competing claims of economic efficiency and social justice' (Pierson et al., 2014: 4). But it was a highly gendered and unequal settlement in terms of its structures and outcomes. Indeed, the Beveridge Report embedded an ideology of maternalism where women were seen primarily as wives and mothers leading to a process of familialisation (Cochrane and Clarke, 2001: 77). A gendered family where care is the woman's responsibility served industrial capitalism well, providing the social production of society though the unpaid work of women.

The postwar social settlement came under increasing pressure during the fiscal crisis of the 1970s and subsequent rise of neo-liberalism, as social spending came increasingly to be seen as a source of labour market rigidity and drain on growth. This prompted a discursive policy shift towards welfare state retrenchment and the introduction of behavioural conditionality requirements designed to move people 'from welfare to work'. Underlying this policy shift was a reinvigorated belief in the primacy of the market as the most efficient means of organising public goods and services and, indeed, of securing the wellbeing of private individuals. 'Social' citizenship became eclipsed by 'market' citizenship and the economic imperative for citizens to sell their labour to derive subsistence from employment.

This market orientation has continued to inform social policy development to this day, notwithstanding a brief period from the late 1990s to the mid-2000s when a new 'third way' of the social investment welfare state gained in ascendency (Jenson, 2012). Rather than viewing social spending as a burden on economic competitiveness, this model argued for the contribution of early investments in human capital formation and in measures to reconcile work and family to promote employment and economic growth. It also advocated for the importance of active labour market policies in facilitating flexible labour force transitions over the life-course, and the 'dual role' of social spending in reducing socio-economic inequalities while enhancing productivity and growth. However, the economic crisis of 2008 halted political momentum for a more 'enabling' welfare state model as countries turned towards cost-containment, welfare state retrenchment, and a renewed emphasis on 'work-first' activation (Umney et al., 2018).

Throughout these post-war transformations, the objective of the welfare state has been understood primarily in relation to the goal of economic growth and fiscally sustainable development, rather than social reproduction or ecological sustainability. That is, modern welfare states have increasingly been premised not on enabling sustainable forms of flourishing but on capacitating economic growth (Fitzpatrick, 2004; Gough, 2015), viewing this as both a pre-condition for the progressive expansion of social security as well as an outcome of social policy investments. In this way, as Hirvilammi (2020: 391) argues, contemporary welfare state models inherently assume 'a virtuous circle' between welfare and economic growth. The danger of this orientation is that not only does it carry a substantial ecological footprint, it also targets social policies on the basis of treating citizens as economic inputs and means of production rather than as persons with the substantive freedom to flourish in a multiplicity of ways. Within this productivist value framework, recognising and accounting for the value of essential reproductive activities such as caring for people, the environment, or our democracies is notoriously difficult. It relies on demonstrating their added economic value, an act of accounting that fundamentally misrecognises why people care about and undertake activities of a reproductive nature (Barry, 2019). 


\section{Towards a sustainable welfare state: the ethics of care}

Any contemporary drive to promote the synergy of collective and individual welfare must reposition the need for sustainability, broadly understood, to be at the heart of any renewed welfare project, drawing from feminist analyses that understand the welfare state as not just a set of services but a set of ideas about society, including social reproduction and family life (Barry, 2021).

From the perspective of sustainability and social reproduction, the 1942 Beveridge Report was always inadequate. The absence of awareness of the evil of climate change can be contextualised in light of the values and conditions of the 1940's, but even eight decades ago feminists argued the Beveridge Report lacked an analysis of gender, care and interdependence, an analysis now understood to be central to the concept of human and planetary sustainability. The feminist concept 'ethics of care' (Fisher and Tronto, 1990) emphasises the social and political value of caring as a human activity, highlighting the importance of human connections, interdependence, reciprocity, and the ties between relationship and responsibility. This perspective overcomes the boundaries of public and private spheres, embracing the social totality of relations, including human care relations and our ecological relationship with nature. Each welfare state has a different care regime characterised by a different relationship between the state, market, family and communities in the provision of care but in all states care work is gendered, is low paid and unpaid, and often happens in poor and precarious conditions (Barry, 2021). Care is central to a sustainable welfare state as well as the reproduction of society and the social infrastructure or connective tissue which holds society together. This essential nature of care work and its central role in the functioning of economies and societies (Oxfam, 2021) became especially visible during the pandemic, along with the disproportionate burdens placed on women. High levels of violence within the home have been revealed and violence against female health workers, women migrants and domestic workers has also intensified (UN, 2020).

A sustainable welfare state needs to make care an urgent priority, shifting it from its marginal and residual position in international economic and social strategies. Care, social reproduction, and eco-social goals need to be at the heart of a reimagined welfare project and debates on the welfare state for the next twenty years. Collective provision, as Coote argues in this themed section, also contributes to ecological sustainability, preventing various kinds of harm that might require resource-intensive public agency interventions, setting protocols for sustainable use of natural resources (including infrastructure, energy, non-renewable resources, and transport), promoting environmental education from a young age.

\section{Overview of contributions}

The articles in this thematic section, to differing degrees, assess the degree to which we can break existing cognitive locks and enable new insights into transitioning beyond hitherto productivist paradigms to develop sustainable welfare from a multiplicity of perspectives.

The thematic section opens with a state-of-the-art review, in which Max Koch assesses the potential for social policy, and welfare reform more broadly, to contribute to an ecological transition. He begins by unpacking the scientific evidence showing that 
economies must urgently transition towards a post-growth political economy. This leads on to the concept of 'sustainable welfare', which he draws on as an 'umbrella term' to capture welfare and social policy models aimed at keeping patterns of economic and social participation within ecological limits, or the 'safe operating space' outlined by Raworth (2017) in her concept of the doughnut of social and planetary boundaries. ${ }^{2}$ Koch's argument is that we have already far exceeded this environmental ceiling, and that contemporary welfare and social policies have been complicit in this process. Against this, the concept of sustainable welfare subsumes the economy within ecological and social limits to embed welfare systems within 'the ecological context' (Hirvilammi, 2020: 6). He likens the scale of recalibration needed to the post-war transformation period when social policy was animated by the project of reconstituting the welfare-work nexus and regulating capitalist growth. Similarly, he concludes, 'a more interventionist state is required to grapple with the climate emergency'.

In the second contribution, lan Gough takes up this challenge of thinking through the scale of transformation required to put welfare states on a more sustainable footing, comparing two possible trajectories of reform. The first is oriented by a Green New Deal (GND) framework of decarbonising economies, largely through upfront investment in renewable energy projects and carbon reduction technologies. While this approach may partly address the ecological transition needed for our economies, it does little to address social inequality. For this reason, Gough argues that any reorientation of our political economies around a GND framework must be complemented by a social guarantee to meet basic needs through a minimum income guarantee and the collective provision of essential goods and services. Nonetheless, the scale of change may not go far enough in recomposing consumption to keep resource use within planetary limits. This leads him to consider a second scenario, which he terms an 'economy of egalitarian sufficiency', that places limits on wealth accumulation and the consumption of high-carbon luxury goods. This scenario calls for an even more interventionist welfare state, that would reduce working hours and heavily regulate, tax, or even prohibit luxury and wasteful consumption. This raises the critical question of how to determine the 'necessitousness' of consumption and to distinguish people's needs from their wants and luxuries. It is a question that Gough has wrestled with throughout his work (cf. Doyal and Gough, 1991), and one which may only be satisfactorily addressed, from a political view, through forms of dialogic democracy as in the examples he cites of the UK and French Citizens' Climate Assemblies.

In the third contribution, the role of UBS in contributing to a more sustainable welfare model is further considered by Anna Coote. Taking up the theme of an economy of sufficiency, Coote develops an argument for UBS as fusing two objectives: reforming welfare systems to ameliorate widening inequalities (universality) and transforming our provisioning systems to reduce GHG emissions and containing resource-use within the 'safe operating space' (Raworth, 2017) of meeting social needs within planetary limits (sufficiency). She envisages UBS as both a 'radical and pragmatic' reform proposal, in that there are clear immediate steps that we can quickly take to expand collective and public provision of goods and services while, in the longer-term, UBS calls for a deep recovery of the collective responsibility and enhanced social solidarity of pooling resources and sharing risks that characterised the post-war settlement. This collective ideal, as Coote highlights, has been steadily eroded over the past forty years by the ascendency of neoliberal market ideology and spending cuts that have left today's public services 
'starved of power and resources'. However, she argues that a return to a logic of 'exercising collective responsibility' for meeting human needs can bring enormous benefits in terms of equity, efficiency, solidarity, and sustainability through minimising profit-extraction, promoting redistribution, and embedding principles of mutual aid and reciprocity. The question of what form of income support might complement collective provisioning of need is addressed by Larrufa, McGann and Murphy, in the last paper.

The final three contributions turn towards the implications of 'sustainable welfare' for the nexus between welfare and work, and the intersections between income support and labour market participation. In so doing, the contributions also seek to ground the concept of sustainable welfare in the capabilities approach to wellbeing pioneered by Sen, and subsequently developed in the work of Nussbaum, Anderson, and others.

In their article, 'Towards a capability-oriented eco-social policy: elements of a normative framework', Bonvin and Laruffa offer a 'post-productivist' interpretation of the capabilities approach that seeks to reclaim the capabilities approach from how it has been employed in the social investment literature as legitimating a focus on promoting flexible labour market transitions and human capital development in the service of economic growth. Although capabilities theorists have often valued economic growth as means to flourishing, Bonvin and Laruffa draw on Sen's 'anthropological conception' of people as simultaneously 'receivers', 'doers' and 'judges', to show how the project of enabling people to lead the life they have reason to value can be reconciled with social policy models that decouple welfare from growth. Critical to doing so, they argue, is enabling people to exercise their agency as 'doers' in a plurality of ways rather than the current predominant focus on motivating citizens to become economic actors and using active labour market policies to catalyse labour market participation. Contesting the link between labour market inclusion and capabilities promotion, they argue that the capability approach demands recognition and support for other forms of doing beyond paid work such as civic participation and forms of reproductive labour that are anchored in an ethics of care or the 'capability to take care of the world'.

At stake is how we envisage the value of work and what it means for people to contribute productively to society beyond the commodification of their labour. This question is directly taken up in the final two contributions, which re-envisage how active labour market and income support policies might be reconciled with a post-productivist or eco-social orientation. In her contribution, Fiona Dukelow asks whether 'activation' policies can continue to have any role in a sustainable welfare state. She raises this question considering the increasingly demanding, coercive, and work-first focused approach that countries have taken to activation, particularly since the financial crisis. The upshot of this reform direction, she argues, has been to make work more precarious while making economies even more unequal and unsustainable. Against this direction of travel, Dukelow argues not for an outright decoupling of the welfare-work nexus or end to catalysing participation in employment, but for a recalibration of what we consider valuable as, and about, 'work'. She calls for re-covering 'socially-oriented iterations of activation policy' based on enabling people to participate in socially useful and decent work. Drawing on the example of Ireland's Community Employment programme, she reflects on the potential for active labour market policies to be reconfigured around 'ecosocial' job creation or a postgrowth job guarantee.

The final contribution by Laruffa, McGann, and Murphy builds on this line of argument to consider how income supports and principles of welfare reciprocity might 
be reconfigured to promote more sustainable forms of social and economic participation. They argue for a reinterpretation of Atkinson's concept of a 'participation income' as a form of green conditional basic income that would replace conventional means-tested forms of social assistance and complement UBS and contributory forms of social insurance. In advancing this proposal, they focus on addressing a range of policy and administrative challenges associated with conditioning income support on forms of ecosocial participation. Key amongst these are the challenges of defining socially valued forms of participation and implementing targeted forms of social security in ways that preserve claimants' dignity and self-respect. Drawing on recent experiments in cocreating participation opportunities with social assistance recipients in local government areas in Scotland, Denmark, and the Netherlands, they argue for enabling participation through co-productive implementation structures that rely on appealing to people's intrinsic motivations through the quality and diversity of participation options made available rather than enforcing reciprocity through strict monitoring and sanctions. The PI focus on reciprocity is justified on normative grounds but also on the basis of political expediency: however, the broad concept is largely consistent with arguments for minimum income guarantees (Arnold, 2020), that when combined with universal basic services becomes a social guarantee.

\section{Acknowledgements}

This research has received funding from the European Union's Horizon 2020 research and innovation programme under the Marie Sklodowska-Curie grant agreement no. 841477 and from the Irish Research Council under Grant IRC/COALESCE/2019/56/MURPHY. The views expressed are those of the authors alone. Neither Maynooth University, the European Commission nor Irish Research Council are responsible for any use that may be made of the information in this article.

\section{Notes}

1 https://www.socialguarantee.org/

2 This is the developmental space between the minimum level of resource use required to meet basic human needs through provisioning systems such as the foundational economy, and the upper threshold of an environmental ceiling beyond which any further resource use leads to unsustainable degradation and risks pushing the planet beyond an ecological tipping point.

\section{References}

Arnold, S. (2020) 'Why we need an income guarantee for all', https:/www.opendemocracy.net/en/ oureconomy/why-we-need-income-guarantee-all/ [accessed 07.04.2021].

Barry, J. (2019) 'Green republicanism and a 'Just Transition' from the tyranny of economic growth', Critical Review of International Social and Political Philosophy, DOI: doi.org/10.1080/13698230.2019. 1698134.

Barry, U. (2021) The Care Economy, Covid-19 Recovery and Gender Equality - A Summary Report, Brussels: European Parliament.

Béland, D., Marchildon, G. P., Mioni, M. and Petersen, K. (2021) 'Translating social policy ideas: the Beveridge report, transnational diffusion, and welfare state development in Canada, Denmark, and France', Social Policy and Administration, DOI: 10.1111/SPOL.12755. 
Cochrane, A. and Clarke, J. (eds.) (2001) Comparing Welfare States ( ${ }^{\text {nd }}$ edn), London: Open University Press.

Doyal, L. and Gough, I. (1991) A Theory of Human Need, London: Macmillan Education UK.

Fisher, B. and Tronto, J. (1990) 'Toward a feminist theory of caring', in E. Abel and M. Nelson (eds.), Circles of Care: Work and Identity, Albany: SUNY Press.

Fitzpatrick, T. (2004) 'A post-productivist future for social democracy?', Social Policy and Society, 3, 3, 213-22.

Gough, I. (2015) 'Welfare states and environmental states: a comparative analysis', Environmental Politics, $25,1,24-47$.

Hirvilammi, T. (2020) 'The virtuous circle of sustainable welfare as a transformative policy idea', Sustainability, 12, 1, 391.

Hirvilammi, T. and Koch, M. (2020) 'Sustainable welfare beyond growth', Sustainability, 12, 5, 1824.

Jackson, B. (2013) 'Social democracy', in M. Freedan, L. Sargent, and M. Stears (eds.), The Oxford Handbook of Political Ideologies, Oxford: Oxford University Press, 348.

Jenson, J. (2012) 'Redesigning citizenship regimes after neoliberalism: moving towards social investment', in N. Morel, B. Palier, and J. Palme J (eds.), Towards a Social Investment Welfare State? Ideas, Policies and Challenges, Bristol: Policy Press, 27-44.

Laurent, E. (2020) 'The four worlds of the social-ecological state', https://www.socialeurope.eu/the-fourworlds-of-the-social-ecological-state [accessed 25.06.2020].

Morel, N., Palier, B. and Palme, J. (2012) 'Beyond the welfare state as we knew it', in N. Morel, B. Palier, and J. Palme (eds.), Towards a Social Investment Welfare State? Ideas, Policies and Challenges, Bristol: Policy Press, 1-30.

Oxfam (2021) The Inequality Virus, https://www.oxfam.org/en/research/inequality-virus [accessed 31.08.2021].

Pierson, C., Castles, F. and Naumann, I. (2014) The Welfare State Reader (3 ${ }^{\text {rd }}$ edn), Cambridge: Polity Press.

Raworth, K. (2017) Doughnut Economics, London: Random House Business.

Thorne, P. (2021) 'Six key takeaways from the new climate change report', https://www.rte.ie/brainstorm/ 2021/0809/1239772-ipcc-report-2021-key-takeaways/ [accessed 23.08.2021].

Umney, C., Greer, I., Onaran, Ö. and Symon, G. (2018) 'The state and class discipline: European labour market policy after the financial crisis', Capital and Class, 42, 2, 333-51.

United Nations (UN) (2020) 'The shadow pandemic: violence against women during Covid-19', https:// www.unwomen.org/en/news/in-focus/in-focus-gender-equality-in-covid-19-response/violence-againstwomen-during-covid-19 [accessed 10.11.2021].

Wignaraja, K. and Horvath, B. (2020) 'Universal basic income is the answer to the inequalities exposed by Covid-19', https://www.weforum.org/agenda/2020/04/covid-19-universal-basic-incomesocial-inequality/ [accessed 26.06.2020]. 